\title{
THE IMPACT OF ETHICAL IDEOLOGIES ON THE JUDGMENT OF ONLINE MARKETING COMMUNICATIONS ETHICS IN THE TOURISM MARKET - TOURISM STUDENTS' PERSPECTIVE
}

\author{
Dina Lončarić
}

$\mathrm{PhD}$, Associate Professor, University of Rijeka, Faculty of Tourism and Hospitality Management, Primorska 42, p.p. 97, 51410 Opatija, Croatia; e-mail: dina.loncaric@fthm.hr

\author{
Mateja Balent \\ MA in Economics, Dravska 40, Draškovec, 40323 Prelog, Croatia; \\ e-mail:mateja.balent@gmail.com
}

\begin{abstract}
SUMMARY
The purpose of this paper is to study the relationship between ethical ideologies and the judgment of online marketing communications ethics in the tourism market. The aim of the research is also to establish a relationship between the judgement of online communications ethics and behavioural intentions. The paper is based on empirical research conducted using the scenario method and survey method. The Ethics Position Questionnaire (EPQ) was used to measure ethical ideology along two dimensions, relativism and idealism. Five scenarios were designed, describing potentially ethically ambiguous situations. A relationship was established between ethical ideologies and ethical judgements of online marketing communications. The study proved that respondents who scored higher on the idealism scale have more rigid criteria with regard to online communications ethics and were better at recognising ethically ambiguous situations. A relationship between the ethical judgements of the described situations and behavioural intention was also established. Although topics relating to online communications on the tourism market are extensively researched, there are few studies dealing with ethical judgement of such communications. The special contribution of this paper is in the fact that research includes students of tourism and hospitality who will, in the near future, find themselves in situations where they will need to make, and take moral responsibility for, decisions regarding communications in the tourism market. Therefore, this research contributes both to theory and practice.
\end{abstract}

Key words: online marketing communication ethics, online marketing communications, ethical ideologies, tourism students, Ethics Position Questionnaire 


\section{INTRODUCTION}

The application of new technologies in business activities is an indispensable part of the process of modern management, decision making and business operations (Budimir, 2013). Especially important is the Internet, whose development has made it possible to introduce innovations, including new ways of communicating with the market, into everyday practice. Internet marketing communication is today a vital form of communication and selling in the tourism market. For instance, in 2015, global online travel sales totalled 533.52 billion U.S. dollars and is projected to grow to 762.34 billion U.S. dollars in 2019 (Statista, 2016). The data show that two-thirds of travellers use online channels to make accommodation bookings (TripAdvisor, 2016). However, at the same time the Internet represents a "new environment for unethical behaviour" (Freestone and Mitchell, 2004; p. 126). The reason for this is the so-called ethical lag which occurs when the speed of technological change far exceeds that of ethical development (Kracher and Corritore, 2004). Namely, the development of technology and its application in communications is not matched by the pace at which regulations are made to provide unambiguous rules of conduct, sometimes leaving marketers with ethical dilemmas when communicating with the market.

Numerous scholars have studied the ethics of marketing communications (Gilbert et al., 1997; Muhcină and Popovici, 2008; Javernik, Podnar and Jančić, 2011; Drumwright and Murphy, 2009; Ruiz and Llaguno, 2012), as well as Internet-related ethics (Bush, Venable and Bush, 2000; Román and Cuestas, 2008; Yoon, 2011; Chiang and Lee, 2011; Limbu, Wolf and Lunsford, 2012; Limbu, Wolf and Lunsford, 2011; Palmer, 2005; Sama and Shoaf, 2002; Williamson et al., 2011; Bush et al., 2003) and ethics in tourism (Wheeler, 1995; Campelo, Aitken and Gnoth, 2010). It was established that ethics in decision making depends on a number of factors. (Hunt and Vitell, 1986; Laczniak and Murphy, 1991; Singhapakdi and Vitell, 1990; Vitell and Muncy, 1992; Abromaityté-Sereikiené, 2008; Bateman, Valentine and Rittenburg, 2012; Cherry and Fraedrich, 2002; Batory, Neese and Batory, 2005; Lin, Ho and Jen, 2008; Boyd, 2010). For example, Hunt and Vitell (1986, p.8) identified four categories of factors for decision in marketing situations: cultural environment, industry environment, organizational environment and personal experience. According to Robbins ethical or unethical behaviour is under the influence of individual characteristics, structural variables and organizational culture (Robbins, 1991, p.134). Ford and Richardson (1994) divided the factors which influence moral behaviour into two groups: individual and situational factors. Individual factors refer to those given by birth such as gender and age, and factors which are the result of experience and socialization such as education, personality and attitudes. Making the marketing decisions is in the managers' domain, so it depends on their system of values and moral principles. This is confirmed by Pini and Carolli (2004) who established that the managers' moral characteristics influence the accepting of social responsibility. Frederick, Post and Davies (1992) also stress personal values and the managers' moral as an important guideline of ethical behaviour in doing business. When the behaviour in certain business situations is not determined by the rules or procedures, the critical factors which the decision-making depends on, refer to the managers' individual characteristics. Singhapakdi et al. (1996) claim that "marketers must first perceive ethics and social responsibility to be important before their behaviours are likely to become more ethical and reflect greater social responsibility." This perception depends on a number of factors such 
as cultural differences, economic and legal/political environment, organizational ethical climate and gender (Singhapakdi et al., 2001). Taking that into consideration we can conclude that the manager's attitude regarding the importance of ethics and social responsibility in doing business is important for moral behaviour in marketing decision-making.

Special attention in the literature centres on ethical ideologies, which are the research subject of this paper. Although a series of papers, investigating the effect of ethical ideologies on the perceived ethics of various situations in business and in life, have been published (Vitell and Singhapakdi, 1993; Kim, 2003; Valentine and Bateman, 2011; VanMeter et al., 2013; Kleiser et al., 2003; Kujala, 2001), there has been little research concerning the impact of ethical ideology on the judgement of communication practices on the Internet in the context of tourism and the hotel industry. Moreover, "little attention has been paid in the ethics literature to the dilemmas facing tourism managers and its students" (Hudson and Miller, 2005). Therefore, the aim of this article is to study in greater detail the judgment of Internet marketing communications ethics in the tourism market and the relationship between the perception of ethics and behavioural intention. The results of this study will fill the aforementioned research gap.

The purposes of this study are: (1) to examine how tourism and hospitality students understand the major ethical dilemmas which refer to Internet communication; (2) to measure the level of idealism and relativism of students and determine whether there are any differences in ethical judgements with regard to ethical ideologies, and (3) to examine how their judgement of Internet communication ethics affects their behavioural intentions.

The structure of the paper comprises five sections. The sections following the introduction provide a literature review, describe the methodology, and present research results. The paper ends with a discussion and conclusions.

\section{LITERATURE REVIEW}

\section{1 Ethical issues in Internet marketing communications}

Marketing ethics refers to ethics in individual functional areas, and is a more or less independent sub-specialisation of business ethics (Brinkmann, 2002). Murphy et al. define ethical marketing as "practices that emphasize transparent, trustworthy, and responsible personal and/or organizational marketing policies and actions that exhibit integrity as well fairness to consumers and other stakeholders" (Murphy et al., 2005, p. XVIII).

It is a fact that marketers are faced with many ethical dilemmas in their everyday work. The term "ethical dilemma" refers to "a situation where it is not clear what choice morality requires" (Murphy et al., 2005, p. 3). Most ethical issues refer to the main tools of marketing management, respectively product policies, marketing communications, pricing approaches and distribution practices (Crane and Matten, 2004, p. 269.). The greatest challenges are those found in the field of marketing communications (Grbac, 2012, p. 259-260.) The foremost rights of consumers that should be respected in communications are the right to privacy and the right to truthful and 
honest communication (Crane and Matten, 2004, p. 270). Criticism aimed at communications in practice can be divided into two levels: the individual and the societal. At the individual level, criticism refers to "the use of misleading or deceptive practices that seek to create false beliefs about specific products or companies in the individual consumer's mind, primarily in order to increase the propensity to purchase. At the social level, the main concern is with the aggregate social and cultural impacts of marketing communications on everyday life, in particular their role in promoting materialism and reifying consumption" (Crane and Matten, 2004, p. 271.). De Pelsmacker et al. (2010, p. 613) highlight stereotyping, targeting vulnerable groups, covert marketing and controversial marketing communication messages as unethical communication practices.

At a time when the virtual world, thanks to the Internet, is suppressing the physical world, and when a huge number of business processes are conducted in a virtual environment (Dukić, 2013), special attention should be given to communications ethics. Namely, the rapid development of the Internet has numerous side effects which could be considered unethical. The Word of Mouth Marketing Association (WOMMA, 2009) published the following Internet marketing communications practices that it sees as being unethical: paying people to praise a product while hiding the fact that they work for the company, false representation to consumers, the use of false identities in online discussions to promote a product, the use of automated programmes for posting inappropriate or irrelevant comments on blogs and other online communities, sending unwanted emails (spam), intentionally giving false or misleading information, and intentionally destroying the property of others to promote one's own product (Javernik, Podnar and Jančić, 2011).

In its Code of Ethics, the Word of Mouth Marketing Association (WOMMA) speaks in favour of core values: trust, integrity, respect, honesty, responsibility, and privacy. Also, to help marketers make decisions and resolve ethical dilemmas, the American Marketing Association has adapted a Statement of Ethics, stating that marketers must do no harm, and should foster trust in the marketing system and embrace ethical values. Ethical values are honesty (to be forthright in dealings with customers and stakeholders), responsibility (to accept the consequences of our marketing decisions and strategies), fairness (to balance justly the needs of the buyer with the interests of the seller), respect (to acknowledge the basic human dignity of all stakeholders), transparency (to create a spirit of openness in marketing operations), and citizenship (to fulfil the economic, legal, philanthropic and societal responsibilities that serve stakeholders). There is no doubt that, in the coming period, marketers and tourism professionals will be faced with numerous ethical dilemmas, and their behaviour will, among other things, depend on the extent to which they consider a specific communications practice to be right or not.

\section{2 Ethical ideologies}

Perceptions and judgements of ethics depend on numerous factors. Singhapakdi et al. (1996) claim that "marketers must first perceive ethics and social responsibility to be important before their behaviours are likely to become more ethical and reflect greater social responsibility." This perception depends on a number of factors such as cultural differences, economic and legal/ 
political environment, organizational ethical climate and gender (Singhapakdi et al., 2001). Frederick, Post and Davies (1992) stress personal values and the managers' moral as an important guideline of ethical behaviour in doing business. When the behaviour in certain business situations is not determined by rules or procedures, the critical factors, upon which decision-making depends, refer to the individual characteristics of managers.

This paper focuses on the impact of an individual's moral philosophies or ethical ideologies on the judgement of ethics. "Ethical ideology refers to a system of ethics used to make moral judgments, which offers guidelines for judging and resolving behaviour that may be ethically questionable" (Henle et al. 2005, p. 219). Forsyth (1980) has identified two basic components of ethical ideology: relativism and idealism. Relativism is conceptualised as "the extent to which the individual rejects universal moral rules in favour of relativism" (Forsyth, 1980, p. 176). The concept of idealism was explained as the degree to which individuals "assume that desirable consequences can, with the 'right' action, always be obtained" (Forsyth, 1980, p. 176). Taking into account these two dimensions of ethical ideologies, individuals can be divided into four segments based on the level to which they are relativistic and idealistic.

Individuals who are highly relativistic and highly idealistic are called situationalists. They reject the application of universal moral principles and believe that moral acts should have positive consequences for all persons affected by an action or decision. Absolutists are highly idealistic but non-relativistic and believe that ethical actions result in positive consequences but also conform with universal moral principles (Barnett, Bass and Brown, 1994). The third group (subjectivists) consists of people who are highly relativistic but non-idealistic. They reject moral rules, and believe that moral decisions are the subject of individual assessment. Finally, exceptionalists who are low on idealism and low on relativism accept moral rules in principle, but they are prone to violate moral rules in order to avoid negative consequences.

Previously, the studies of a number of scholars proved that moral ideologies have a significant impact on ethical judgements regarding various business situations (Barnett, Bass and Brown, 1994; Davis et al., 2001; Valentine and Bateman, 2011) including marketing (Vitell and Singhapakdi, 1993; Kleiser et al., 2003). Ethical ideologies affect the way people function in the workplace (VanMeter et al., 2013). They influence ethical decisions at the individual level (e.g., Barnett et al., 1996; Vitell et al., 1993). "Idealism and relativism are important components of a businessperson's ethical framework, and in many cases, the two factors are found to be moderate predictors of ethical judgment and behaviour" (Valentine and Bateman, 2011). Valentine and Bateman (2011) prove on a sample of business students that idealism is associated with increased ethical issue recognition, and relativism is associated with decreased ethical intention in different sales situations. The following hypothesis is therefore proposed:

H1: Moral ideologies affect ethical judgement regarding online marketing communications on the tourism market. Persons scoring higher on the idealism scale are more rigid in their ethical judgement of ambiguous situations than persons with lower scores on the scale (H1a). Persons scoring higher on the relativism scale are less stringent in their ethical judgement of ambiguous situations than persons with lower scores on the scale (H1b). 
Ethical judgements of specific situations, including Internet-based communications, affect the behaviour of individuals. Namely, "recognizing an ethical issue should consistently enhance the likelihood that an individual will become more committed to behaving in an ethical manner" (Valentine and Bateman, 2011). For the moral decision-making process to begin, a person must be able to recognize the moral issue (Jones, 1991). Considering the general theories of consumer behaviour and model of planned behaviour developed by Fishbein and Ajzen (1975), Hunt and Vitell (1986) postulated that ethical judgements impact on behaviour through intervening variables of intention. Also, other authors emphasize the role of moral judgment and moral intent in moral behaviour (Jones 1991). Therefore, the following hypothesis is proposed:

H2: There is a positive relationship between the positive perception of online marketing communications ethics and behavioural intentions. Persons who consider business situations as being ethically less problematic display greater intention to behave in the same way.

\section{METHODOLOGY}

\section{1 Research instrument}

A questionnaire comprising three sets of questions was used to gather data. The first set of questions, referring to moral ideologies, consisted of 20 statements to measure the ethical viewpoints of idealism and relativism. Ethical ideologies were measured using the Ethics Position Questionnaire (EPQ) scale developed by Forsyth (1980). Unlike the original 9-point scale, this study, along with many others (Rawwas; 1996; Steenhaut \& van Kenhove, 2006; Vitell et al. 1996; Javernik et al. 2011), applies a 5-point Likert-type scale, with 1 meaning completely disagree and 5, completely agree. The major reason for the application of a 5 -point scale is that it is simpler for respondents to use.

The second set of questions involved five short scenarios (Table 1) depicting ethically ambiguous situations in Internet marketing communications in the tourism market. The scenario method is one of the most commonly used methods in studying marketing ethics (Vitell and Singhapakdi, 1993; Hoffman, Couch and Lamont, 1998; Giacobbe and Segal, 2000). The scenarios illustrated issues relating to the use of clients' personal data, the misuse of clients' personal data in promotional purposes, misleading advertising of hotel services, the use of fake blogs, and forum spamming. Each scenario, with the exception of one, presented an ethically ambiguous situation. The first scenario was not ethically ambiguous as it presented a situation that complied with the norms of Internet communications. The reason it was depicted to respondents was to test how carefully they read the text and filled out the questionnaire. To rate the respondents' perception of the ethics of individual forms of marketing communications, they were asked to carefully read each scenario and then reply whether they deem the behaviour of the individual in the scenario to be ethical or not. They rated the level of ethical behaviour on a 5-point Likert-type scale, ranging from completely unethical (1) to completely ethical (5). In addition to giving their perception of the ethics of the situations described in the scenarios, the respondents were also asked to state whether they themselves would behave in the same way. The respondents rated their agreement to this statement on a scale of 1 (I completely disagree) to 5 (I completely agree). 
The third set of dichotomous questions aimed to establish whether the respondents had attended a course of business ethics during their studies, whether the contents of any other courses they attended included business ethics, and whether during their previous schooling they had listened to lectures in ethics as a subject at school. The respondents responded to the questions with Yes or No.

The fourth set of questions referred to the socio-demographic data of respondents (age, sex, student status, work experience).

Table 1. Scenario descriptions

SCENARIO 1: Using clients' personal data

A travel agency cares about the satisfaction of its service users and makes it a practice to ask its clients to fill out a questionnaire concerning their satisfaction with services rendered by the agency. Clients are asked to state their personal data and e-mail address if they wish to receive information about new offers and special bargains and are promised that their data will not be used for any other purpose. Accordingly, the travel agency regularly sends its offers to the clients on its e-mail list.

SCENARIO 2: Misuse of clients' personal data for promotional purposes

The owner of a small family-run hotel organises numerous events for its guests, such as various celebrations, excursions, etc. To promote the hotel's offering, the owner decides to take advantage of the Internet and posts several photographs and films shot during various events in which the hotel's guests took part. The guests are not previously informed of this.

SCENARIO 3: False advertising of hotel services

A hotel is using its website to promote its products and services. Pictures of the hotel and its services/facilities are posted on the website, and among these are photos of the swimming pool and spa centre, together with opening hours. At present, however, the swimming pool is out of order due to malfunctioning installations. Repairs are expected to last some ten days. An employee in the sales and marketing department suggests to the hotel manager to post an announcement on the website that the pool is closed. The manager considers it is not necessary as the malfunction will be repaired shortly and, besides, not all guests use the swimming pool. He instructs the employee to continue advertising pool services on the website. Should any of the guests complain about the closed pool, they will be offered a discount on the price of massages.

SCENARIO 4: False blog

A restaurant chain has employed a new marketer for promotion. In order to improve sales, the marketer analyses the channels and techniques previously used in promoting the restaurant's services. He notes that the advantages of the Internet are poorly exploited and proposes to engage and pay the services of a person who would write favourably about the restaurant's services on their private blog, thus extoling and promoting the restaurant. 


\section{SCENARIO 5: Forum spam}

Recently, the sales volume of a hotel enterprise has been in gradual decline, although no objective reasons for this exist. The hotel's management sees the cause for the decline in the fact that guests tend to book via the Internet, where competition in this segment is becoming increasingly fierce. The marketer responsible for Internet marketing feels the enterprise is not capitalising sufficiently on the opportunities provided by the Internet and proposes to implement software that will post hotel advertisements on various forums, regardless of the forum's topic.

\subsection{Sample description}

The study concerning ethical judgement of Internet marketing communications on the tourism market involved 529 university students of tourism and hospitality. Both undergraduate and graduate students were included. Research was conducted in January 2014. The students were surveyed during regular classes using a paper-and-pencil approach. An analysis of the completed questions showed that 468 or $88.47 \%$ of the questionnaires were properly completed. Sixty-six questionnaires were rejected, mainly because they were not completed in full. Table 2 presents the sample structure.

Table 2. Socio-demographic profile of respondents ( $N=468)$

\begin{tabular}{|l|c|c|c|}
\hline \multicolumn{1}{|l|}{ Items } & & Frequency & Percentage \\
\hline \multirow{3}{*}{ Age } & $18-20$ & 128 & 27.35 \\
& $21-25$ & 311 & 66.45 \\
& $26-30$ & 20 & 4.27 \\
& $31-35$ & 6 & 1.28 \\
& $36-40$ & 0 & 0 \\
\hline \multirow{3}{*}{ Gender } & 41 and over & 3 & 0.6 \\
\hline \multirow{3}{*}{ Status } & Female & 327 & 69.87 \\
& Male & 141 & 30.13 \\
\hline \multirow{3}{*}{ Employment } & Full-time student & 204 & 43.59 \\
& Part-time student & 264 & 56.41 \\
& Permanently employed & 55 & 32.48 \\
& Casual work & 261 & 11.75 \\
\hline
\end{tabular}

Source: Research results 
It is evident that the largest number of respondents belongs to the 21-25 age-group (66.45\%). Female students $(69.87 \%)$ prevailed in the sample, which is in line with the student structure at the university. Full-time students accounted for $43.59 \%$ of respondents, and part-time students for $56.41 \%$. The work experience of the students was also investigated, with results showing that $55.77 \%$ of the students were engaged in casual work, $32.48 \%$ had no work experience, while $11.5 \%$ were permanently employed.

\section{FINDINGS}

\section{1 Results of descriptive statistics}

The respondents were asked to read the scenarios and judge whether the individual activities described in scenarios are, in their opinion, ethical or not. They were also asked how they would behave if they were in the same situation and had to make a decision. Table 3 presents the respondents' scores.

Table 3. Ethical judgement of Internet communications and behavioural intention

\begin{tabular}{|l|c|c|c|c|}
\hline \multirow{2}{*}{ SCENARIOS } & \multicolumn{2}{|c|}{$\begin{array}{c}\text { ETHICAL } \\
\text { JUDGEMENT }\end{array}$} & \multicolumn{2}{c|}{$\begin{array}{c}\text { BEHAVIOURAL } \\
\text { INTENTION }\end{array}$} \\
\cline { 2 - 5 } & MEAN & SD & MEAN & SD \\
\hline 1. Use of clients' personal data & 3.97 & 1.060 & 4.00 & 1.109 \\
\hline $\begin{array}{l}\text { 2. Misuse of clients' personal data for } \\
\text { promotion purposes }\end{array}$ & 2.45 & 1.235 & 2.49 & 1.381 \\
\hline 3. False advertising of hotel services & 2.37 & 1.210 & 2.35 & 1.377 \\
\hline 4. Fake blog & 3.01 & 1.380 & 3.10 & 1.401 \\
\hline 5. Forum spam & 3.74 & 1.084 & 3.78 & 1.092 \\
\hline
\end{tabular}

Source: Research results

Based on an analysis of the above results, it can be concluded that the students perceive the first scenario $(M=3.97, S D=1.060)$ as being the only ethically unambiguous scenario. Were they in the position of the tourism worker, the respondents would behave in the same way (4.00). Thus, the respondents believe that the clients' personal data needed for sending them marketing messages should only be used with the willing approval of the clients and should not be used for any other purposes. The respondents consider Scenario 4, referring to the posting of a fake blog, as being marginally ethical $(M=3.01, S D=1.380)$. They would behave in the same way. They also judged Scenario $5(M=3.74, S D=1.084)$, regarding forum spam, as being ethical, because they consider it ethical to post hotel advertisements on various forums. They reported they would behave like the 


\section{Lončarić, M. Balent: The Impact of Ethical Ideologies on the Judgment of Online Marketing... Zbornik Veleučilišta u Rijeci, Vol. 7 (2019), No. 1, pp. 127-147}

marketer in the scenario $(M=3.78, S D=1.092)$. It is important to note that Scenarios 4 and 5 were given as examples of non-ethical behaviour, while the students perceived them as being ethical and stated they would behave in a like manner. On the other hand, the students perceived Scenario $3(M=2.37, S D=1.210)$, concerning the false advertising of hotel services, as being unethical. The students correctly perceived the situation as being unethical and they would not behave in that way $(M=2.35, S D=1.377)$. Similarly, they perceived Scenario $2(M=2.45, S D=1.235)$, the misuse of clients' personal data for promotional purposes, as being unethical and their behavioural intentions indicate they would not behave as depicted in the scenario $(M=2.49, S D=1.381)$.

\section{2 Testing the formulated hypotheses}

To test the hypotheses, the respondents were asked to first rate the statements measuring their ethical viewpoint according to the ideologies of idealism and relativism. The results of descriptive statistics are presented in Table 4.

Prior to testing the formulated hypothesis regarding the correlation of ethical ideologies and perceptions of Internet communications ethics, the dimensionality and reliability of the EPQ scale was tested, considering that the original scale was translated from the English language and that a 5-point scale was applied instead of a 9-point scale. A principal components analysis with varimax rotation of the factor axis was carried out constraining the solution to two factors. The criteria for the number of factors extracted and variables retained were based on theoretical background, i.e. Forsyth's theory of ethical ideology and significance of factor loadings. Factor loadings above 0.30 taking into account the number of respondents (Hair 2006, p. 128) were considered as acceptable. Therefore, one item from the idealism sub-scale (id_7: "Deciding whether or not to perform an act by balancing the positive consequences of the act against the negative consequences of the act is immoral.") was deleted because of low factor loading.

To check the reliability of the scales, Cronbach's alpha coefficients were calculated. Cronbach's alpha was 0.819 for the idealism sub-scale and 0.816 for the relativism sub-scale. Indicators of internal consistency for all factors exceeded the threshold value of 0.70 , which is considered to be the accepted limit (Nunnally, 1978). The results presented in Table 4 were obtained following exploratory factor analysis and reliability analysis for the EPQ scale.

Table 4. Results of descriptive statistics, factor and reliability analysis for the EPQ scale

\begin{tabular}{|l|c|c|c|c|c|c|}
\hline Item & Item & $\begin{array}{c}\text { Factor } \\
\text { loading }\end{array}$ & $\begin{array}{c}\text { Total } \\
\text { variance } \\
\text { explained } \\
(\%)\end{array}$ & $\begin{array}{c}\text { Alpha } \\
\text { coefficient }\end{array}$ & Mean & SD \\
\hline FACTOR 1 - IDEALISM & & $\mathbf{2 2 . 7 0 8}$ & $\mathbf{0 . 8 1 9}$ & $\mathbf{4 . 2 9}$ & 0.60 \\
\hline id_6 & $\begin{array}{l}\text { If an action could harm } \\
\text { an innocent other, then } \\
\text { it should not be done. }\end{array}$ & .747 & & & 4.59 & 0.80 \\
\hline
\end{tabular}




\begin{tabular}{|c|c|c|c|c|c|c|}
\hline id_5 & $\begin{array}{l}\text { One should not } \\
\text { perform an action } \\
\text { which might in any way } \\
\text { threaten the dignity } \\
\text { and welfare of another } \\
\text { individual. }\end{array}$ & .752 & & & 4.44 & $0 ., 90$ \\
\hline id_4 & $\begin{array}{l}\text { One should never } \\
\text { psychologically or } \\
\text { physically harm } \\
\text { another person. }\end{array}$ & ,735 & & & 4.50 & 0.91 \\
\hline id_9 & $\begin{array}{l}\text { It is never necessary to } \\
\text { sacrifice the welfare of } \\
\text { others. }\end{array}$ & ,725 & & & 4.29 & 1.03 \\
\hline id_3 & $\begin{array}{l}\text { The existence of } \\
\text { potential harm to } \\
\text { others is always wrong, } \\
\text { irrespective of the } \\
\text { benefits to be gained. }\end{array}$ & ,646 & & & 3.94 & 1.05 \\
\hline id_8 & $\begin{array}{l}\text { The dignity and welfare } \\
\text { of people should be } \\
\text { the most important } \\
\text { concern in any society. }\end{array}$ & ,637 & & & 4.47 & 0.85 \\
\hline id_2 & $\begin{array}{l}\text { Risks to another should } \\
\text { never be tolerated, } \\
\text { irrespective of how } \\
\text { small the risk might be. }\end{array}$ & ,605 & & & 4.06 & 1.01 \\
\hline id_1 & $\begin{array}{l}\text { A person should } \\
\text { make certain that } \\
\text { their actions never } \\
\text { intentionally harm } \\
\text { another even to a small } \\
\text { degree. }\end{array}$ &, 584 & & & 4.43 & 091 \\
\hline id_10 & $\begin{array}{l}\text { Moral actions are those } \\
\text { which closely match } \\
\text { the most "perfect" } \\
\text { action. }\end{array}$ &, 570 & & & 3.91 & 0.98 \\
\hline \multicolumn{2}{|c|}{ FACTOR 2 - RELATIVISM } & & 17,742 & 0,816 & 3.69 & 0.70 \\
\hline rel_5 & $\begin{array}{l}\text { Questions of what is } \\
\text { ethical for everyone } \\
\text { can never be resolved } \\
\text { since what is moral or } \\
\text { immoral is up to the } \\
\text { individual. }\end{array}$ & ,733 & & & 3.76 & 1.17 \\
\hline
\end{tabular}




\begin{tabular}{|c|c|c|c|c|}
\hline rel_6 & $\begin{array}{l}\text { Moral standards are } \\
\text { simply personal rules } \\
\text { which indicate how a } \\
\text { person should behave, } \\
\text { and are not to be } \\
\text { applied in making } \\
\text { judgments of others. }\end{array}$ & 660 & 3.60 & 1.25 \\
\hline rel_8 & $\begin{array}{l}\text { Rigidly codifying an } \\
\text { ethical position that } \\
\text { prevents certain types } \\
\text { of actions could stand } \\
\text { in the way of better } \\
\text { human relations and } \\
\text { adjustment. }\end{array}$ & 658 & 3.66 & 1.11 \\
\hline rel_7 & $\begin{array}{l}\text { Ethical considerations } \\
\text { in interpersonal } \\
\text { relations are so } \\
\text { complex that } \\
\text { individuals should be } \\
\text { allowed to formulate } \\
\text { their own individual } \\
\text { codes. }\end{array}$ & ,651 & 3.67 & 1.08 \\
\hline rel_9 & $\begin{array}{l}\text { No rule concerning } \\
\text { lying can be } \\
\text { formulated; whether } \\
\text { a lie is permissible or } \\
\text { not permissible totally } \\
\text { depends upon the } \\
\text { situation. }\end{array}$ & 651 & 3.64 & 1.26 \\
\hline rel_3 & $\begin{array}{l}\text { Moral standards } \\
\text { should be seen as being } \\
\text { individualistic; what } \\
\text { one person considers } \\
\text { to be moral may be } \\
\text { judged to be immoral } \\
\text { by another person. } \\
\end{array}$ & 646 & 4.17 & 1.05 \\
\hline rel_10 & $\begin{array}{l}\text { Whether a lie is judged } \\
\text { to be moral or immoral } \\
\text { depends upon } \\
\text { the circumstances } \\
\text { surrounding the action. }\end{array}$ & ,576 & 3.60 & 1.27 \\
\hline
\end{tabular}




\begin{tabular}{|l|l|l|l|r|r|}
\hline rel_4 & $\begin{array}{l}\text { Different types of } \\
\text { moralities cannot } \\
\text { be compared as to } \\
\text { "rightness". }\end{array}$ & ,573 & & 3.93 & 1.06 \\
\hline rel_2 & $\begin{array}{l}\text { What is ethical varies } \\
\text { from one situation and } \\
\text { society to another. }\end{array}$ &, 530 & & 3.85 & 1.04 \\
\hline rel_1 & $\begin{array}{l}\text { There are no ethical } \\
\text { principles that are so } \\
\text { important that they } \\
\text { should be a part of any } \\
\text { code of ethics }\end{array}$ &, 449 & & 3.08 & 1.20 \\
\hline
\end{tabular}

Source: Research results

It is evident that respondents were more inclined to the moral philosophy of idealism, since the mean score for the idealism sub-scale was 4.29 (SD = 0.60), and for the realism sub-scale, 3.69 (SD $=0.60$ ). To categorise respondents into one of four ethical ideologies, we used the median scores as cut-off points. The medians for idealism and relativism were 4.44 and 3.8, respectively. Of the total number of respondents, $27.2 \%(n=127)$ were classified as situationalists, $30.2 \%(n=141)$ as exceptionalists, $25.3 \%(n=118)$ as absolutists and $17.3 \%(n=81)$ as subjectivists.

To test hypothesis $\mathrm{H} 1$, correlation analysis was first conducted to determine whether there was a correlation between ethical approaches and the perception of ethics. Table 5 presents the correlation coefficients between the perception of ethics, and idealism and relativism.

Table 5. Correlation coefficients

\begin{tabular}{|c|c|c|c|c|c|c|}
\hline \multirow{2}{*}{\multicolumn{2}{|c|}{ IDEOLOGY }} & \multicolumn{5}{|c|}{ SCENARIO } \\
\hline & & \multirow{2}{*}{$\frac{1}{.109 *}$} & \multirow{2}{*}{$\frac{2}{-.163^{* *}}$} & \multirow{2}{*}{$\begin{array}{l}3 \\
. .195^{* *}\end{array}$} & \multirow{2}{*}{$\begin{array}{l}4 \\
-.071\end{array}$} & \multirow{2}{*}{$\begin{array}{l}5 \\
.060\end{array}$} \\
\hline IDCA ICM & $\begin{array}{l}\text { Pearson } \\
\text { Correlation }\end{array}$ & & & & & \\
\hline IDEALISIVI & $\begin{array}{l}\text { Sig. } \\
\text { (2-tailed) }\end{array}$ & .019 & .000 & .000 & .127 & .199 \\
\hline \multirow{2}{*}{ RELATIVISM } & $\begin{array}{l}\text { Pearson } \\
\text { Correlation }\end{array}$ & $.113^{*}$ & $.188^{* *}$ & .026 & $.138^{* *}$ & .059 \\
\hline & $\begin{array}{l}\text { Sig. } \\
\text { (2-tailed) }\end{array}$ & .014 & .000 & .579 & .003 & .206 \\
\hline
\end{tabular}

Source: Research results 


\section{Lončarić, M. Balent: The Impact of Ethical Ideologies on the Judgment of Online Marketing... Zbornik Veleučilišta u Rijeci, Vol. 7 (2019), No. 1, pp. 127-147}

Results presented in Table 5 point to a weak but statistically significant correlation between the idealism scale and the perception of Internet communications ethics. Correlation is present in three cases: in Scenario 1 (use of clients' personal data), Scenario 2 (misuse of clients' personal data for promotional purposes) and Scenario 3 (false advertising of hotel services). The correlation coefficients of Scenarios 2 and 3 were negative, meaning that the respondents who scored high on the idealism scale also considered those scenarios as being less ethical. A weak but statistically significant correlation also exists between the dimensions of relativism and the perception of ethics. This correlation can be observed in Scenario 1 (use of clients' personal data), Scenario 2 (misuse of clients' personal data for promotional purposes) and Scenario 4 (fake blog). Respondents who scored higher on the relativism scale considered the ethically ambiguous situations and decisions as being correct.

Table 6 shows the mean scores and standard deviations on the perceptions of Internet communication ethics for each scenario across four different groups.

Table 6: Mean scores

\begin{tabular}{|l|c|c|c|c|c|c|c|c|c|c|}
\hline & \multicolumn{10}{|c|}{ Scenario } \\
\hline & \multicolumn{2}{|c|}{1} & \multicolumn{2}{|c|}{2} & \multicolumn{2}{c|}{3} & \multicolumn{2}{|c|}{4} & \multicolumn{2}{|c|}{5} \\
\hline & $M$ & SD & $M$ & SD & $M$ & SD & $M$ & SD & $M$ & SD \\
\hline Situationalists & 4.16 & .955 & 2.49 & 1.234 & 2.13 & 1.191 & 3.09 & 1.394 & 3.84 & 1.080 \\
\hline Exceptionalists & 3.80 & 1.116 & 2.41 & 1.141 & 2.55 & 1.180 & 3.01 & 1.259 & 3.63 & 1.031 \\
\hline Absolutists & 3.93 & 1.092 & 2.16 & 1.191 & 2.20 & 1.114 & 2.73 & 1.471 & 3.77 & 1.057 \\
\hline Subjectivists & 4.06 & 1.017 & 2.85 & 1.352 & 2.69 & 1.329 & 3.31 & 1.357 & 3.69 & 1.221 \\
\hline
\end{tabular}

Source: Research results

It is evident that respondents perceived Scenarios 2 and 3 as being the least ethical. To examine the differences in the groups' perceptions based on ethical ideology, a one-way multivariate analysis of variance (MANOVA) was performed. Ethical ideology was the independent variable, while the dependent variables referred to the perception of the ethics of all five scenarios. Preliminary testing to check the assumptions for conducting multivariate analysis of variance did not note any violation of the assumptions. A statistically significant difference was determined between the members of different ideological groups with regard to their perception of ethics $F(15,1267,5)=3.037, p<.0005$; Wilk's $\Lambda=0.907$, partial $\left.\eta^{2}=0.32\right)$.

As a follow-up method, a series of univariate variance analyses (ANOVAs) were performed (Table 7). 
Table 7. ANOVA results

\begin{tabular}{|c|c|c|c|c|c|r|}
\hline $\begin{array}{c}\text { INDEPENDENT } \\
\text { VARIABLE }\end{array}$ & SCENARIO & $\mathrm{df}$ & $\begin{array}{c}\text { Mean } \\
\text { Square }\end{array}$ & $\mathrm{F}$ & Sig. & $\begin{array}{c}\text { Partial Eta } \\
\text { Squared }\end{array}$ \\
\hline \multirow{3}{*}{ IDEOLOGIES } & 1 & 3 & 3.101 & 2.807 & .039 & .018 \\
\cline { 2 - 7 } & 2 & 3 & 7.774 & 5.246 & .001 & .033 \\
\cline { 2 - 7 } & 3 & 3 & 7.697 & 5.399 & .001 & .034 \\
\cline { 2 - 7 } & 4 & 3 & 5.817 & 3.105 & .026 & .020 \\
\cline { 2 - 7 } & 5 & 3 & 1.099 & .932 & .425 & .006 \\
\hline
\end{tabular}

Source: Research results

The univariate $F$ tests showed the significant impact of ideology on the perceptions of Scenario 1 $(F=2.807, d f=(3,463), p=.039)$ Scenario $2(F=7.774, d f=(3,463), p=.001)$, Scenario $3(F=5.399$, $\mathrm{df}=(3,463), \mathrm{p}=.001)$ and Scenario $4(\mathrm{~F}=5.817, \mathrm{df}=(3,463), \mathrm{p}=.026)$. The differences between groups for Scenario 5 were not significant. Post hoc comparisons (Tukey HSD) showed significant differences between perceptions of ethics between different groups (Table 8).

Table 8. Mean differences between groups

\begin{tabular}{|c|c|c|c|c|c|}
\hline SCENARIO & (I) Group & (II) Group & $\begin{array}{c}\text { Mean } \\
\text { Difference } \\
(I-I I)\end{array}$ & Std. Error & Sig. \\
\hline 1 & Situationalists & Exceptionalists & $.36^{*}$ & .129 & .030 \\
\hline \multirow[t]{2}{*}{2} & \multirow{2}{*}{ Subjectivists } & Exceptionalists & $.44^{*}$ & .170 & .048 \\
\hline & & Absolutists & $.69^{*}$ & .176 & .001 \\
\hline \multirow[t]{4}{*}{3} & \multirow{2}{*}{ Situationalists } & Exceptionalists & $-.41^{*}$ & .146 & .026 \\
\hline & & Subjectivists & $-.56^{*}$ & .170 & .006 \\
\hline & \multirow{2}{*}{ Subjectivists } & Situationalists & $.56^{*}$ & .170 & .006 \\
\hline & & Absolutists & $.49^{*}$ & .172 & .025 \\
\hline 4 & Absolutists & Subjectivists & $-.58^{*}$ & .198 & .018 \\
\hline
\end{tabular}

* The mean difference is significant at the 0.05 level

Source: Research results

The biggest mean difference was found between absolutists and subjectivists regarding Scenario $2(M=2.16, S D=1.191$ for absolutists and $M=2.85, S D=1.352$ for subjectivists $)$ and Scenario 4 $(M=2.73, S D=1.471$ for absolutists and $M=3.31, S D=1.357$ for subjectivists). Absolutists, with high idealism and low relativism, perceived the misuse of clients' personal data for promotional purposes and fake blogs as being more unethical than did subjectivists with low idealism and high relativism. The results presented lead to the confirmation of hypothesis $\mathrm{H} 1$. 


\section{Lončarić, M. Balent: The Impact of Ethical Ideologies on the Judgment of Online Marketing... Zbornik Veleučilišta u Rijeci, Vol. 7 (2019), No. 1, pp. 127-147}

Correlation analysis was conducted to determine whether a correlation exists between the perception of Internet marketing communications ethics and behavioural intention. Table 9 presents an overview of the Pearson correlation coefficients between the perception of ethics and behavioural intention in all five scenarios.

Table 9. Correlation coefficients between the judgment of ethics and behavioural intention

\begin{tabular}{|c|c|c|c|c|c|c|}
\hline \multirow{2}{*}{\multicolumn{2}{|c|}{ SCENARIO }} & \multicolumn{5}{|c|}{ BEHAVIOURAL INTENTION } \\
\hline & & 1 & 2 & 3 & 4 & 5 \\
\hline \multirow{5}{*}{ 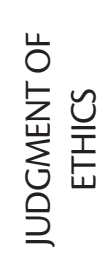 } & 1 & $.714^{* *}$ & -.036 & -.017 & .032 & $.165^{* *}$ \\
\hline & 2 & .053 & $.755^{* *}$ & $.255^{* *}$ & $.155^{* *}$ & .040 \\
\hline & 3 & -.009 & $.236^{* *}$ & $.755^{* *}$ & $.211^{* *}$ & -.044 \\
\hline & 4 & .055 & $.151^{* *}$ & $.115^{*}$ & $.812^{* *}$ & $.205^{* *}$ \\
\hline & 5 & $.126^{* *}$ & .025 & -.037 & $.183^{* *}$ & $.765^{* *}$ \\
\hline
\end{tabular}

Correlation is significant at the 0.05 level

** Correlation is significant at the 0.01 level

Source: Research results

It is evident that positive and statistically significant correlations exist between the perception of ethics and behavioural intentions in all five scenarios. The correlation coefficients range between 0.714 and 0.812 , with $p<0.05$. This leads to the conclusion that the more the respondents consider certain communication activities as being less ethically ambiguous, the greater the probability that they would also behave in the same manner. Hence, hypothesis $\mathrm{H} 2$ is confirmed.

\section{CONCLUSION}

Today, marketers are faced with numerous ethical dilemmas, especially when it comes to Internet marketing, because legislation is lagging behind the rapidly developing information and communication technologies. The ethical judgement of marketing activities, affecting how individuals behave, depends on numerous factors, one of them being ethical ideologies.

The study indicates that the students of tourism and hospitality included in the survey can mostly distinguish ambiguous ethical situations from unambiguous ones and score higher on the idealism scale than on the relativism scale. Although the correlation coefficients between ethical ideologies and the ethical judgement of individual scenarios are rather low, it is evident that the respondents who scored higher on the idealism scale are more uncompromising in their ethical judgements of marketing communications than the respondents who are more disposed to relativism. This is in line with the findings of Valentine and Bateman (2011), who proved on a sample of business students that idealism is associated with increased ethical issue recognition, while relativism is associated with decreased ethical intention in different sales situations. 
The study also suggests that ethical judgement influences the behavioural intention of respondents. If the respondents consider a marketing activity as being less ethically ambiguous, there is a greater probability that they would behave in the same way.

The results presented draw attention to the importance of educating students in the field of ethics and social responsibility. The study, however, did not explore the differences in attitudes among respondents with regard to previous education in ethics. This is one of the paper's limitations and further research should clearly be conducted to determine whether differences exist in ethical ideologies and the ethical judgement of scenarios with regard to previous education in the field of ethics. Another limitation of this paper is the sample which includes students of a single university. It would be interesting to make comparisons between students of different cultures as well as students of different areas of science. Research could focus on determining whether any differences exist with regard to the respondents' sociodemographic profile. Future studies could also investigate the ethical judgement of students regarding other marketing activities and new forms of communications developing daily.

\section{REFERENCES}

Abromaitytè-Sereikienè, L. (2008) “Factors Influencing Ethics of Marketing Decisions in Lithuanian Media”, Engineering Economics, 56(1), 29-36.

Barnett, T., Bass, K. and Brown, G. (1994) "Ethical ideology and ethical judgment regarding ethical issues in business", Journal of Business Ethics, 13(6), 469-480. doi: 10.1007/BF00881456.

Barnett, T., Bass, K. and Brown, G. (1996) "Religiosity, Ethical Ideology, and Intentions to Report a Peer's Wrongdoing", Journal of Business Ethics, 15(11), 1161-1174. doi: https://doi.org/10.1007/BF00412815

Bateman, C. R., Valentine, S. and Rittenburg, T. (2012) "Ethical Decision Making in a Peer-to-Peer File Sharing Situation: The Role of Moral Absolutes and Social Consensus", Journal of Business Ethics, 115(2), 229-240. doi: 10.1007/ s10551-012-1388-1.

Batory, S. S., Neese, W. and Batory, A. H. (2005) "Ethical Marketing Practices: An Investigation of Antecedents, Innovativeness and business performance", Journal of American Academy of Business, 6(2), 135-142.

Boyd, D. (2010) “Ethical determinants for generations X and Y”, Journal of Business Ethics, 93(3), 465-469. doi: 10.1007/ s10551-009-0233-7.

Brinkmann, J. (2002) "Business and Marketing Ethics as Professional Ethics: Concepts, Approaches and Typologies", Journal of Business Ethics, 41(1/2), 159. - 178. doi.org/10.1023/A:1021318710382

Budimir, M. (2013) "Uloga novih tehnologija u procesu odlučivanja”, Ekonomski vjesnik / Econviews - Review of Contemporary Business, Entrepreneurship and Economic Issues, XXVI(2), 573-584.

Bush, V. et al. (2003) "Investigating the Relationship between Corporate values and Practices of marketing Organizations and Internet Ethics: An Exploratory Study", Marketing Management Journal, 13(2), 1-13.

Bush, V. D., Venable, B. T. and Bush, A. J. (2000) "Ethics and Marketing on the Internet: Practitioners ' Perceptions of Societal, Industry and Company Concerns", Journal of Business Ethics, 23(3), 237-248.

Campelo, A., Aitken, R. and Gnoth, J. (2010) “Visual Rhetoric and Ethics in Marketing of Destinations”, Journal of Travel Research, 50(1),3-14. doi:10.1177/0047287510362777.

Cherry, J. and Fraedrich, J. (2002) "Perceived risk, moral philosophy and marketing ethics: mediating influences on sales managers' ethical decision-making", Journal of Business Research, 55(12), 951-962. doi: 10.1016/S01482963(00)00215-0. 


\section{Lončarić, M. Balent: The Impact of Ethical Ideologies on the Judgment of Online Marketing...}

Zbornik Veleučilišta u Rijeci, Vol. 7 (2019), No. 1, pp. 127-147

Chiang, L. and Lee, B. (2011) “Ethical Attitude and Behaviors Regarding Computer Use”, Ethics \& Behavior, 21(6), 481497. doi: 10.1080/10508422.2011.622181.

Crane, A., Matten, D., (2004) “Business ethics: A European Perspective”, Oxford University Press, Oxford

Davis, M. A., Andersen, M. G., Curtis, M. B. (2001) “Measuring Ethical Ideology in Business Ethics: A Critical Analysis of the Ethics Position Questionnaire", Journal of Business Ethics, 32(1), 35-53. https://doi.org/10.1023/A:1010701417165

De Pelsmacker, Geuens, M., Van den Bergh, J. (2010) “Marketing Communications: A European Perspective, Fourth edition, Pearson Education, Edinburhg

Drumwright, M. E. and Murphy, P. E. (2009) "The Current State of Advertising Ethics: Industry and Academic Perspectives", Journal of Advertising, 38(1), 83-108. doi: 10.2753/JOA0091-3367380106.

Dukić, S. (2013) “Model e-marketinga humanitarnih organizacija u Republici Hrvatskoj”, Ekonomski vjesnik / Econviews, XXVI(1), 199-214.

Fishbein, M., Ajzen, I. (1975) "Belief, Attitude, Intention, and Behavior: An Introduction to Theory and Research, Reading" , MA: Addison-Wesley.

Ford, R. C., Richardson, W. D. (1994) „Ethical decision making: a rewiev of the empirical literature“, Journal of Business Ethics, 13(3), $205-221$.

Forsyth, D. R. (1980) “A Taxonomy of Ethical Ideologies", Journal od Personality and Social Psychology, 39(1), 175-184

Frederick, W. C., Post, J.E. and Davies, K. (1992) Business and society: corporate strategy, public policy, ethics, McGrawHill, New York, NY

Freestone, O. and Mitchell V.-W. (2004) "Generation Y Attitudes Towards E-ethics and Internet-related Misbehaviours", Journal of Business Ethics, 54(2), 121-128.

Giacobbe, R. W., Segal, M. N. (2000) "Comparative Analysis of Ethical Perceptions in Marketing Research:U.S.A.vs Canada", Journal of Business Ethics, 27(3), 229-245. https://doi.org/10.1023/A:1006121122073

Gilbert, F. W., Barnes, J. H., Nwachukwu, S. L. S., Vitel, S. J. (1997) "Ethics and Social Responsibility in Marketing: An Examination of the Ethical Evaluation of Advertising Strategies", Journal of Business Research, 39(2), 107-118, https:// doi.org/10.1016/S0148-2963(96)00146-4

Global digital travel sales 2014-2019, Statista, http://www.statista.com/statistics/499694/forecast-of-online-travel-salesworldwide/, 22.6.2016.

Grbac, B. (2012) "Creation and value exchange”, (Stvaranje i razmjena vrijednosti) EFRI, Rijeka

Henle, C. A., Giacalone, R. A., Jurkiewicz, C. L. (2005) "The role of ethical ideology in workplace deviance", Journal of Business Ethics, 56(3), 219-230. doi: https://doi.org/10.1007/s10551-004-2779-8

Hoffman, J. J., Couch, G., Lamont, B.T. (1998) "The Effect of Firm Profit versus Personal Economic Well Being on the Level of Ethical Responses Given by Managers", Journal of Business Ethics, 17(3), 239-244. https://doi. org/10.1023/A:1017936322433

Hudson, S. and Miller, G. (2005) “Ethical orientation and awareness of tourism students", Journal of Business Ethics, 62(4), 383-396. doi: 10.1007/s10551-005-0850-8.

Hunt, S.D. and Vitell, S. (1986) "A General Theory of Marketing Ethics", Journal of Macromarketing, 6(1), 5-16.

Javernik, P., Podnar, K. and Jančić, Z. (2011) "Etične percepcije potrošnikov v viralnem marketinškem komuniciranju", Akademija MM, 10(17), 13-25.

Jones, T. M. (1991) "Ethical Decision Making by Individuals in Organization: An Issue - Contigent Model", The Academy of Management Review, 16(2), 366-395. doi: 10.5465/AMR.1991.4278958

Kim, Y. (2003) "Ethical Standards and Ideology Among Korean Public Relations Practitioners", Journal of Business Ethics, 42(3), 209-223. doi: 10.1023/A:1022281507601. 
Kleiser, S. B. et al. (2003) "Ethical ideologies: Efficient Assessment and Influence on Ethical Judgments of Marketing Practices", Psychology \& Marketing, 20(1,), 1-21. doi: 10.1002/mar.

Kracher, B. and Corritore, C. L. (2004) “Is There a Special E-Commerce Ethics?", Business Ethics Quarterly, 14(1), 71-94. https://doi.org/10.5840/beq20041417

Kujala, J. (2001) "A multidimensional approach to Finnish managers' moral decision-making", Journal of Business Ethics, 34(3-4), 231-254. doi: 10.1023/A:1012583424721.

Laczniak, G. R. and Murphy, P. E. (1991) “Fostering ethical marketing decisions”, Journal of Business Ethics, 10(4), 259-271. doi: $10.1007 / B F 00382965$.

Limbu, Y. B., Wolf, M. and Lunsford, D. (2012) "Perceived ethics of online retailers and consumer behavioral intentions: The mediating roles of trust and attitude", Journal of Research in Interactive Marketing, 6(2), 133-154. doi: $10.1108 / 17505931211265435$.

Limbu, Y. B., Wolf, M. and Lunsford, D. L. (2011) “Consumer's perceptions of online ethics and its effects on satisfaction and loyalty", Journal of Research in Interactive Marketing, 5(1), 71-89. doi: 10.1108/17505931111121534.

Lin, C., Ho, Y. and Jen, K. (2008) "An Examination of Cultural Differences in Ethical Decision Making Using the Multidimensional", Social Behavior and Personality, 36(9), 1213-1222.

Muhcină, S. and Popovici, V. (2008) "Ethics in marketing communication", Management \& Marketing, 3(2), 67-77. Available at: http://www.managementmarketing.ro/pdf/articole/103.pdf.

Murphy, P. E., Laczniak, G. R., Bowie, N. E., Klein, T. A. (2005) “Ethical Marketing”, Pearson, Prentice Hall, Upper Saddle River, New Jersey, NY

Palmer, D. E. (2005) "Pop-Ups, Cookies, and Spam: Toward a Deeper Analysis of the Ethical Significance of Internet Marketing Practices", Journal of Business Ethics, 58(1-3), 271-280. doi: 10.1007/sl0551-005-1421-8.

Pini, F. M., Carolli, C. (2004) "Linking Corporate Responsibility to Corporate Performance: A Survey of European Corporations", ESOMAR, Berlin

Rawwas, M. Y. A. (1996) "Costumer ethics:an empirical investigation oft he ethicals beliefs of Austrian consumers", Journal of Business Ethics, 15(9), 1009-1019. https://doi.org/10.1007/BF00705579

Robbins, P. S. (1991), Management, Prentice.Hall, Engelwood Cliffs, NJ

Román, S. and Cuestas, P. J. (2008) "The Perceptions of Consumers Regarding Online Retailers' Ethics and Their Relationship with Consumers' General Internet Expertise and Word of Mouth: A Preliminary Analysis", Journal of Business Ethics, 83(4), 641-656. doi: 10.1007/s10551-007-9645-4.

Ruiz, A. and Llaguno, M. (2012) "Ethics on the corporate websites of the main advertising agencies in Spain 1", Comunicacion Y Sociedad, XXV(1), 367-398.

Sama, L. M. and Shoaf, V. (2002) "Ethics on the Web: Applying moral decision-making to the New Media", Journal of Business Ethics, 36(1-2), 93-103. doi: 10.1023/A:1014296128397.

Singhapakdi, A. and Vitell, S. J. (1990) "Marketing Ethics: Factors Influencing Perceptions of Ethical Problems and Alternatives", Journal of Macromarketing, 10(1), 4-18. doi: 10.1177/027614679001000102.

Singhapakdi, A., Karande, K., Rao, C. P., Vitell, S. J. (2001) „How Important are Ethics and Social Responsibility?", European Journal of Marketing, 35(1-2), 133 - 152. https://doi.org/10.1108/03090560110363382.

Singhapakdi, A., Vitell, S. J., Rallapalli, K. C. and Kraft, K. L. (1996) "The perceived Role of Ethics and Social Responsibility: A Scale Development", Journal of Business Ethics, 15(11), 1131 - 1140. https://doi.org/10.1007/BF00412812.

Steenhaut, S., van Kenhove, P., (2006) "An Empirical Investigation of the Relationships among a Costumers Personal Values, Ethical Ideology and Ethicals Beliefs", Journal of Business Ethics, 64(2), 137-155.

TripBarometer: Travel Trends 2016, Tripadvisor, 2016, https://d2bxpc4ajzxry0.cloudfront.net/TripAdvisorlnsights/ sites/default/files/downloads/2670/globalreport_us_dec2015.pdf, 22.6.2016. 
D. Lončarić, M. Balent: The Impact of Ethical Ideologies on the Judgment of Online Marketing...

Zbornik Veleučilišta u Rijeci, Vol. 7 (2019), No. 1, pp. 127-147

Valentine, S. R. and Bateman, C. R. (2011) "The Impact of Ethical Ideologies, Moral Intensity, and Social Context on SalesBased Ethical Reasoning", Journal of Business Ethics, 102(1), 155-168. doi: 10.1007/s10551-011-0807-z.

VanMeter, R. a. et al. (2013) "Generation Y's Ethical Ideology and Its Potential Workplace Implications", Journal of Business Ethics, 117(1), 93-109. doi: 10.1007/s10551-012-1505-1.

Vitell, S. J., Lumpkin, J. R., Rawwas, M. Y. A., (1996) "Costumer ethics: an investigation of the ethical beliefs or elderly costumers", Journal of Business Ethics, 10(5), 365-375

Vitell, S. J. and Muncy, J. (1992) "Consumer ethics: An empirical investigation of factors influencing ethical judgments of the final consumer", Journal of Business Ethics, 11(8), 585-597. doi: 10.1007/BF00872270.

Vitell, S. and Singhapakdi, A. (1993) "Ethical Ideology and Its Influence on the Norms and Judgments of Marketing Practitioners", Journal of Marketing Management, 3(1), 1-11.

Vitell, S. J., Rallapalli, K. and Singhapakdi, A., (1993) "Marketing Norms: The Influences of Personal Moral Philosophies and Organizational Ethical Culture", Journal of the Academy of Marketing Science, 21(4), 331-337.

Wheeler, M. (1995) "Tourism marketing ethics: an introduction", International Marketing Review, 12(4), 38-49. doi: $10.1108 / 02651339510097720$.

Williamson, S. et al. (2011) "Ethical Issues in the Age of the Internet: A Study of Students' Perceptions Using the Multidimensional Ethics Scale",Journal of Internet Commerce, 10(2), 128-143. doi: 10.1080/15332861.2011.571992.

WOMMA - http://www.womma.org/ethics/womma-code-of-ethics, (pristupljeno: 19.03.2014.)

Yoon, C. (2011) "Ethical decision-making in the Internet context: Development and test of an initial model based on moral philosophy", Computers in Human Behavior. Elsevier Ltd, 27(6), 2401-2409. doi: 10.1016/j.chb.2011.08.007. 


\title{
UTJECAJ ETIČKIH IDEOLOGIJA NA PROSUDBU ETIČNOSTI ONLINE MARKETINŠKE KOMUNIKACIJE NA TURISTIČKOME TRŽIŠTU - PERSPEKTIVA STUDENATA TURIZMA
}

\section{Dina Lončarić}

Dr. sc., izv. prof., Sveučilište u Rijeci, Fakultet za menadžment u turizmu i ugostiteljstvu, Primorska 42, p.p. 97, 51410 Opatija, Hrvatska; e-mail: dina.loncaric@fthm.hr

\section{Mateja Balent}

Mag. oec., Dravska 40, Draškovec, 40323 Prelog, Hrvatska; e-mail: mateja.balent@gmail.com

\begin{abstract}
SAŽETAK
Surha rada je istražiti povezanost između etičkih ideologija i prosudbe etičnosti online marketinške komunikacije na turističkome tržištu. Cilj je istraživanja, također, utvrditi povezanost između prosudbe etičnosti komunikacije na internetu i namjere ponašanja. Rad se temelji na empirijskom istraživanju u kojemu su primijenjene metoda scenarija i metoda ispitivanja. Kao instrument istraživanja korišten je Upitnik etičke pozicije (EPQ) kojim su mjerene etičke ideologije uvažavajući dimenzije relativizma i idealizma. Oblikovano je pet scenarija kojima su opisane potencijalne etički dvojbene situacije. Utvrđena je povezanost između etičkih ideologija i prosudbe etičnosti u online marketinškoj komunikaciji. Istraživanje je dokazalo da ispitanici koji ostvaruju više rezultate na ljestvici idealizma imaju strože kriterije u odnosu na etičnost $u$ online komunikaciji i bolje raspoznaju etički dvojbene situacije. Utvrđena je i povezanost između prosudbe etičnosti opisanih scenarija i namjera ponašanja. lako su teme u području internetske komunikacije na turističkome tržištu do sada istraživane, ima malo studija koje se odnose na prosudbu etičnosti takve komunikacije. Poseban doprinos ovoga rada očituje se u činjenici da su istraživanjem obuhvaćeni stavovi studenata turizma i ugostiteljstva koji će se u bliskoj budućnosti i sami naći u situacijama u kojima će trebati preuzeti moralnu odgovornost za odluke u vezi s komunikacijom na turističkome tržištu. Ovo istraživanje, stoga, daje doprinos i teoriji i praksi.
\end{abstract}

Ključne riječi: marketinška etika, etičke ideologije, internetska komunikacija, turizam, Upitnik etičke pozicije 